\section{Dr. Hoffmann-Vold replies}

To the Editor:

We highly appreciate the interest $\mathrm{t}^{1,2}$ in our paper ${ }^{3}$ and the reflected and sagacious views from Baron, $\mathrm{et} \mathrm{al}^{4}$. As mentioned, it is still unclear whether mixed connective tissue disease (MCTD) is a distinct disease or might represent an overlap disease. Therefore, we were interested in reviewing the 16 patients with systemic sclerosis (SSc) of our cohort who did not fulfill the 2013 American College of Rheumatology (ACR)/European League Against Rheumatism (EULAR) criteria ${ }^{5,6}$ and the 18 patients with MCTD who did fulfill the criteria in our original paper. Overall, we found that all patients with limited cutaneous SSc, none of the patients with sine scleroderma, and 3/6 patients with pre-scleroderma met the 2013 ACR/EULAR criteria at the last annual followup visit. When looking at the patients with MCTD, 4 patients were deceased. Of the remaining patients, 1 patient was diagnosed with SSc and 4 patients were clinically assessed as MCTD/SSc overlap and still met the 2013 ACR/EULAR criteria. Somewhat surprisingly, several patients did not fulfill the 2013 criteria at the followup visit, mainly because of different assessment of skin thickening of the fingers.

Fourteen of these 18 patients with MCTD were included in the HLA profile study of Norwegian patients with MCTD by Flåm, et $a l^{7}$. Of those, 7 had HLA alleles associated with MCTD and only 1 had HLA alleles associated with SSc.

Altogether, we believe that our study and the followup data clearly show that there is a need for further research on anti-RNP-positive patients, both in terms of genotypes and phenotypes.

ANNA-MARIA HOFFMANN-VOLD, MD, PhD, Rheumatology, Oslo University Hospital, Oslo, Norway. Address correspondence to Dr. A.M. Hoffmann-Vold, Rheumatology, Oslo University Hospital, 0027 Oslo, Norway. E-mail: a.m.hoffmann-vold@medisin.uio.no

\section{REFERENCES}

1. Masi AT, Medsger TA Jr. Progress in the evolution of systemic sclerosis classification criteria and recommendation for additional comparative specificity studies. J Rheumatol 2015;42:8-10.

2. Pope JE. Systemic sclerosis classification: a rose by any other name would smell as sweet? J Rheumatol 2015;42:11-3.

3. Hoffmann-Vold AM, Gunnarsson R, Garen T, Midtvedt $\varnothing$, Molberg $\varnothing$. Performance of the 2013 American College of Rheumatology/European League Against Rheumatism Classification Criteria for Systemic Sclerosis (SSc) in large, well-defined cohorts of SSc and mixed connective tissue disease. J Rheumatol 2015;42:60-3.

4. Baron M, Pope JE, Van den Hoogen F, Khanna D, Fransen J, Johnson SR, et al. Specificity of systemic sclerosis classification criteria. J Rheumatol 2015;42:2512-13.

5. van den Hoogen F, Khanna D, Fransen J, Johnson SR, Baron M, Tyndall A, et al. 2013 classification criteria for systemic sclerosis: an American College of Rheumatology/European League Against Rheumatism collaborative initiative. Ann Rheum Dis 2013; 72:1747-55.

6. van den Hoogen F, Khanna D, Fransen J, Johnson SR, Baron M, Tyndall A, et al. 2013 classification criteria for systemic sclerosis: an American College of Rheumatology/European League Against Rheumatism collaborative initiative. Arthritis Rheum 2013; 65:2737-47.

7. Flåm ST, Gunnarsson R, Garen T; Norwegian MCTD Study Group, Lie BA, Molberg $\varnothing$. The HLA profiles of mixed connective tissue disease differ distinctly from the profiles of clinically related connective tissue diseases. Rheumatology 2015;54:528-35.

J Rheumatol 2015;42:12; doi:10.3899/jrheum.150886 